\title{
Luminescence characteristics of quartz from Brazilian sediments and constraints for OSL dating
}

\author{
CARLOS C.F. GUEDES ${ }^{1}$, ANDRÉ O. SAWAKUCHI ${ }^{1}$, PAULO C.F. GIANNINI ${ }^{1}$, \\ REGINA DEWITT ${ }^{2}$ and VITOR A.P. AGUIAR ${ }^{3}$ \\ ${ }^{1}$ Departamento de Geologia Sedimentar e Ambiental, Instituto de Geociências, \\ Universidade de São Paulo, Rua do Lago, 562, 05508-080 São Paulo, SP, Brasil \\ ${ }^{2}$ Department of Physics, East Carolina University, Howell Science Complex, \\ Rm C-209, 1000 E. 5th Street, Greenville, NC 27858, USA \\ ${ }^{3}$ Instituto de Física, Universidade de São Paulo, Rua do Matão, \\ Travessa R, 187, 05508-090 São Paulo, SP, Brasil
}

Manuscript received on June 1, 2012; accepted for publication on November 23, 2012

\begin{abstract}
This study analyzes the optically stimulated luminescence (OSL) characteristics of quartz grains from fluvial, eolian and shallow marine sands of northeastern and southeastern Brazil, with especial focus on the applicability of the single-aliquot regenerative dose (SAR) dating protocol. All analyzed Brazilian sediments presented relatively high OSL sensitivity and good behavior regarding their luminescence characteristics relevant for radiation dose estimation. However, some samples from the Lençóis Maranhenses region in northeastern Brazil showed inadequate OSL sensitivity correction, hampering the implementation of the SAR protocol and their ability to behave as a natural dosimeter. While the shallow marine and eolian samples showed a narrow and reliable dose distribution, the fluvial sample had a wide dose distribution, suggesting incomplete bleaching and natural doses estimates dependent on age models.
\end{abstract}

Key words: optically stimulated luminescence (OSL) dating, Single-Aliquot Regenerative-Dose protocol (SAR), OSL sensitivity, Brazilian sands.

\section{INTRODUCTION}

Luminescence is the light emitted by some materials, previously exposed to ionizing radiation, when stimulated by some type of activating energy (Huntley 1985). The intensity of the light emitted is proportional to the dose of ionizing radiation which the material was exposed. This relation allows several common minerals such as quartz, feldspar, zircon, and calcite to behave as a natural radiation dosimeter, i.e. record the amount of

Correspondence to: Carlos Conforti Ferreira Guedes

E-mail: ccfguedes@gmail.com ionizing radiation to which they were exposed. The luminescence signal of the mineral grains is emptied naturally by sunlight during sedimentary transport. After burial, when the sediment grains are protected from sunlight, the luminescence signal builds up due to the ionizing radiation derived from nearby natural radionuclides and cosmic rays. As a result, the luminescence signal of buried sediment grains is related to the radiation dose (equivalent dose) absorbed since deposition. Thus, the age of burial can be calculated through the ratio between the equivalent dose and the dose rate (equation 1): 
$\operatorname{Age}[\mathrm{y}]=\frac{\text { Equivalent dose }[\mathrm{Gy}]}{\text { Dose rate }[\mathrm{Gy} / \mathrm{y}]}$

The IS unit of absorbed radiation dose is the Gray (Gy), that is the energy amount per unit mass absorbed by a sample in Joules per kilogram $(1 \mathrm{~Gy}=1 \mathrm{~J} / \mathrm{Kg})$.

Optically stimulated luminescence (OSL) dating is a method of absolute geochronology that has been widely applied in Quaternary studies since its proposition by Huntley (1985) and further development of the Single-Aliquot Regenerative Dose (SAR) protocol by Banerjee et al. (1999) and Murray and Wintle (2000). The SAR dating protocol is now the most frequently applied method to obtain estimates of natural radiation doses. A complete review of the major aspects of the SAR dating protocol is presented by Wintle and Murray (2006). Presently, OSL dating stands out as the only method that makes possible the direct determination of deposition ages for clastic sediments, allowing the definition of a precise and reliable timescale for eolian, shallow marine and fluvial Quaternary deposits. Based on the luminescence of common silicate minerals (e.g. quartz and feldspar), the method is suitable for dating of sandy organicpoor sedimentary deposits, which are beyond other common dating methods such as that based on radiocarbon and U-Th series. Hundreds to thousands of luminescence dating surveys have been performed in Quaternary sediments from Australia, Europe and United States. Despite the huge continental and coastal Quaternary sedimentary record in Brazil, only few dating studies have been performed during the last decades (Poupeau et al. 1984, 1988, Suguio et al. 1999, 2003, Barreto et al. 2001, Teeuw and Rhodes 2004; Giannini et al. 2007, Araujo et al. 2008, Sawakuchi et al. 2008, Tatumi et al. 2008, Tsoar et al. 2009, Feathers et al. 2010, Sallun and Suguio 2010, Soares et al. 2010, Guedes et al. 2011, Bueno et al. 2012). However, luminescence dating has limitations regarding laboratory procedures and sediment characteristics. Using data from single-grain dating of quartz Araujo et al. (2008), Feathers et al. (2010) and Bueno et al. (2012) make considerations regarding the integrity of archeological sites at central Brazil to validate radiocarbon dates. However, still lack information regarding the luminescence behavior of the quartz found in Brazilian sediments and its suitability for radiation dose estimates using the SAR protocol. In this context, the aim of this paper is to discuss the luminescence characteristics of quartz grains from fluvial, eolian and shallow marine sediments of southeastern and northeastern Brazil. We also analyze the influence of these characteristics on results obtained with the OSL-SAR dating protocol.

\section{MATERIALS AND METHODS}

\section{STUDIED LOCATIONS}

The eight sediment samples discussed in this paper are from the Ilha Comprida Barrier in southern Brazil (São Paulo State) and from the Lençóis Maranhenses coastal zone in northeastern Brazil (Maranhão State) (Fig. 1). The Ilha Comprida Barrier samples were previously dated by Sawakuchi et al. (2008) and Guedes et al. (2011). The Ilha Comprida Barrier is a Holocene regressive barrier composed of vegetated stabilized eolian dunes and beach ridges, mainly represented by well sorted very fine to fine high reworked sands (Nascimento et al. 2008, Giannini et al. 2009 Guedes et al. 2011). The inland area of the Ilha Comprida Barrier comprises low to high grade metamorphic rocks and granites (Campanha and Sadowski 1999) drained by the Ribeira de Iguape River under wet subtropical climate.

The Lençóis Maranhenses coastal zone comprises several active and stabilized dunefields (Hesp et al. 2009) composed of well sorted fine sands. These eolian sediments cover the Barreiras Formation (Vasconcelos et al. 2004), which is represented by poorly sorted coarse sandy alluvial sediments. The inland area is composed mainly 
of Paleozoic sedimentary rocks from the Parnaíba Basin (Schobbenhaus and Bellizia 2001), drained by the Parnaíba River that flows from south to north, bounding the west sector of the Maranhão State. This region has a tropical climate with four to six months dry season.

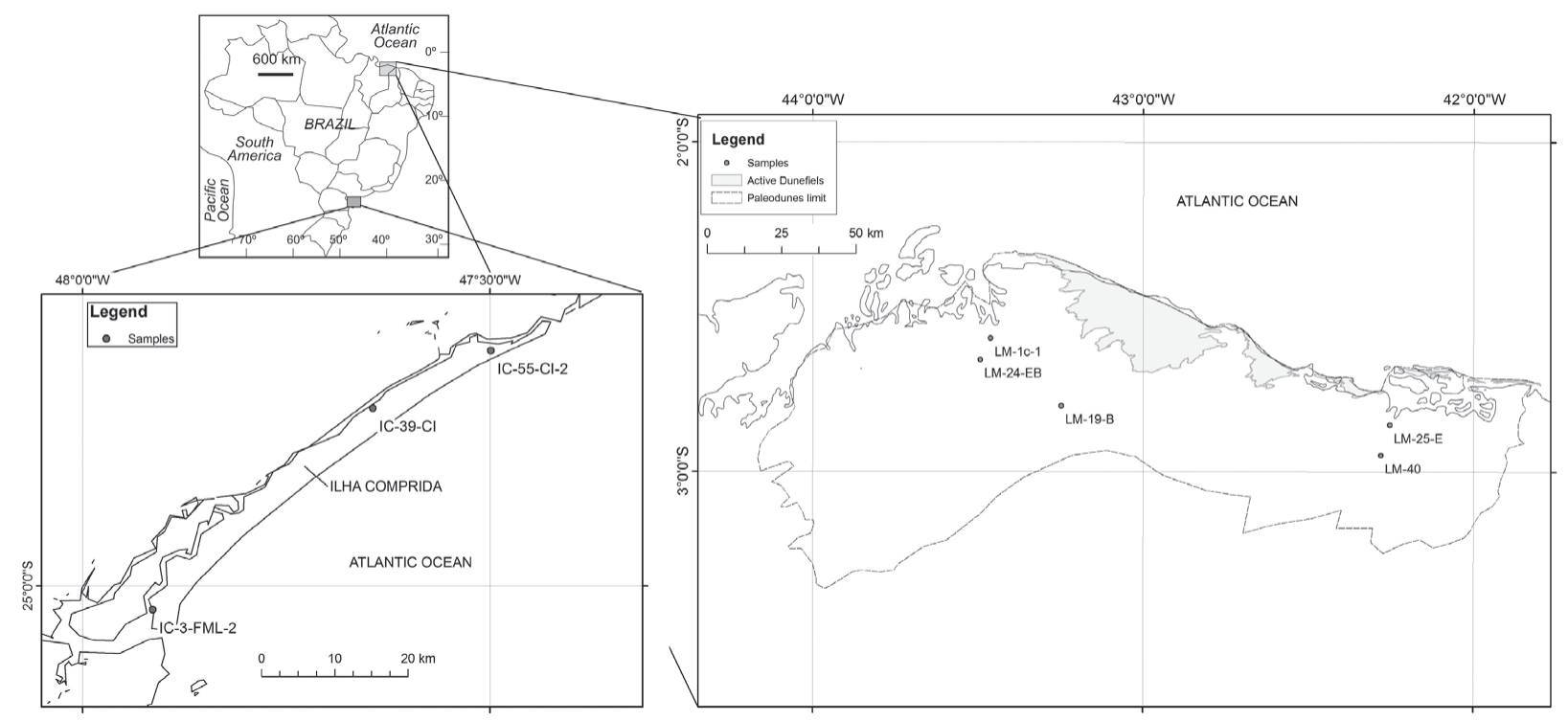

Figure 1 - Sample locations in the Lençóis Maranheses coastal zone (right) and Ilha Comprida Barrier (left).

\section{SAMPLING AND SAMPLE PREPARATION}

OSL samples must be collected avoiding sunlight exposure. Bioturbated horizons should also be avoided to obtain ages of sediment deposition as roots and animals can mix surface grains exposed to sunlight with grains buried during sedimentation. Despite sometimes are difficult to recognize a bioturbated deposit, OSL dating has been used to recognize post-depositional disturbance (Bateman et al. 2007, Bueno et al. 2012). The influence radius of gamma radiation from natural radionuclides is about $30 \mathrm{~cm}$ in sediments. Thus, it is recommended to collect samples at the center of a homogeneous area with $30 \mathrm{~cm}$ radius to facilitate the estimation of the dose rate due to gamma radiation. It is preferable to avoid contacts between depositional facies or pedogenic horizons or zones with different concentration of heavy minerals. In complex sampling sites with composition heterogeneities, all the compositional units that can influence the dose rate should be analyzed (e.g. Feathers et al.
2010). The samples were collected with opaque PVC or aluminum pipes about $30 \mathrm{~cm}$ long by 5 $\mathrm{cm}$ in diameter. From each site additional $\sim 500$ $\mathrm{g}$ of sample material were collected in plastic bags to determine the moisture content and the concentrations of $\mathrm{U}$, Th, and ${ }^{40} \mathrm{~K}$ for estimation of radiation dose-rate. The measurement of the sampling depth, elevation and geographical position are needed to estimate the contribution of cosmic radiation for dose rate.

All laboratory procedures for quartz separation were performed under red light. The sample preparation included separation of 120$150 \mu \mathrm{m}$ sand grains through wet sieving: chemical treatment with $\mathrm{H}_{2} \mathrm{O}_{2} 27 \%, \mathrm{HCl} 3.7 \%$, and $\mathrm{HF}$ $40 \%$ for 40 minutes in order to remove organic matter, $\mathrm{CaCO}_{3}$, and feldspars and the outer shell of the quartz grains affected by alpha radiation, respectively. Density separation with lithium metatungstate solution was performed to separate heavy $\left(>2.75 \mathrm{~g} / \mathrm{cm}^{3}\right)$ from light minerals and quartz from feldspar $\left(<2.62 \mathrm{~g} / \mathrm{cm}^{3}\right)$. 


\section{NATURAL EQUivalent-Dose MEASUREMENT}

OSL measurements were carried out with an automated Risø DA-15 TL/OSL system in the Radiation Dosimetry Laboratory at Oklahoma State University (Stillwater, OK, USA). The builtin ${ }^{90} \mathrm{Sr} /{ }^{90} \mathrm{Y}$ beta source gives a dose rate of 99.6 $\pm 4.1 \mathrm{mGy} / \mathrm{s}$. Optical stimulation was carried out with blue LEDs (470 nm), delivering $31 \mathrm{~mW} / \mathrm{cm}^{2}$ to the sample. The heating rate used was $5^{\circ} \mathrm{C} / \mathrm{s}$. Equivalent-doses were determined using the OSLSAR protocol described in Table I.

TABLE I

Single aliquot regeneration-dose (SAR) protocol used for the samples described in this study.

1. Dose (Di)

2. Preheating at $160-300^{\circ} \mathrm{C}$ for $10 \mathrm{~s}$

3. Measure $\mathrm{OSL}$ at $125^{\circ} \mathrm{C}$ for $100 \mathrm{~s}$ (Ri)

4. Test dose (TDi)

5. Preheating at $160^{\circ} \mathrm{C}$ for $10 \mathrm{~s}$

6. Measure OSL at $125^{\circ} \mathrm{C}$ for $100 \mathrm{~s} \mathrm{(Ti)}$

7. Calculate sensitivity-corrected OSL Li=Ri/Ti

8. Repetition of steps 1-7

Dose RATE MEASUREMENT

The ionizing radiation dose-rate in nature originates mainly from the radioactive decay of ${ }^{232} \mathrm{Th},{ }^{238} \mathrm{U},{ }^{235} \mathrm{U}$ and ${ }^{40} \mathrm{~K}$, and the cosmic rays reaching the sample site. The $\mathrm{U}$, Th and $\mathrm{K}$ concentrations were determined through high resolution gamma spectrometry (Fig. 2a) using a high purity germanium detector (HPGe) inside a $15-\mathrm{cm}$ lead shield in the Laboratório Aberto de Física Nuclear of the Instituto de Física of the Universidade de São Paulo. Conversion factors published by Adamiec and Aitken (1998) were used to obtain dose rate values from radionuclides concentrations. The sample preparation for gamma spectrometry comprised sediment drying and storing in sealed containers for at least 28 days in order to reestablish secular equilibrium in the decay chain after loss of ${ }^{222} \mathrm{Rn}$ during handling of the sample.
The water content, which attenuated the ionizing radiation, was estimated on a duplicate sample collected together with the dating sample.

The contribution of the cosmic radiation to the dose rate (Table II) was calculated according to Barbouti and Rastin (1983) and Prescott and Stephan (1982), using the latitude, longitude, elevation, depth of sample collection, and the density of each sample.

\section{Dose RATE CONSIDERATIONS}

One of the major uncertainties of dose rate calculation is the determination of the water content during the time of sediment burial. The water within the sediment pores attenuates and absorbs the radiation in different rate than sediments, decreasing the effective dose rate. Usually, the water content is estimated on a duplicate sample collected together with the dating sample. However, the water content measured in the laboratory may not reflect the mean water content since burial. Changes in groundwater level and pluviosity (dry or wet season) are difficult to estimate. Thus, the error associated with this measurement must reflect depositional conditions, the local weather and climate changes. Samples collected in stabilized eolian dunes, for example, have an associated error smaller than a fluvial sample collected in outcrops above the groundwater level. Normally, an error of $10 \%$ is assigned to the water content. If uncorrected, the dose rate obtained from the dry sample used in gamma spectrometry is overestimated resulting in age underestimation. For the IC-3-FML-2 sample, an increase of $10 \%$ in the water content results in an $8 \%$ decrease in dose rate and an overestimation of the age by $8 \%$ (Fig. $2 \mathrm{~b}$ ). This sample was collected in an outcrop one meter above the present groundwater table. Additionally, the sample is a shallow marine deposit, which was deposited at a relative sea level higher than the present level. Considering its relatively complex post-depositional history, an error of $10 \%$ was assigned for this sample. 

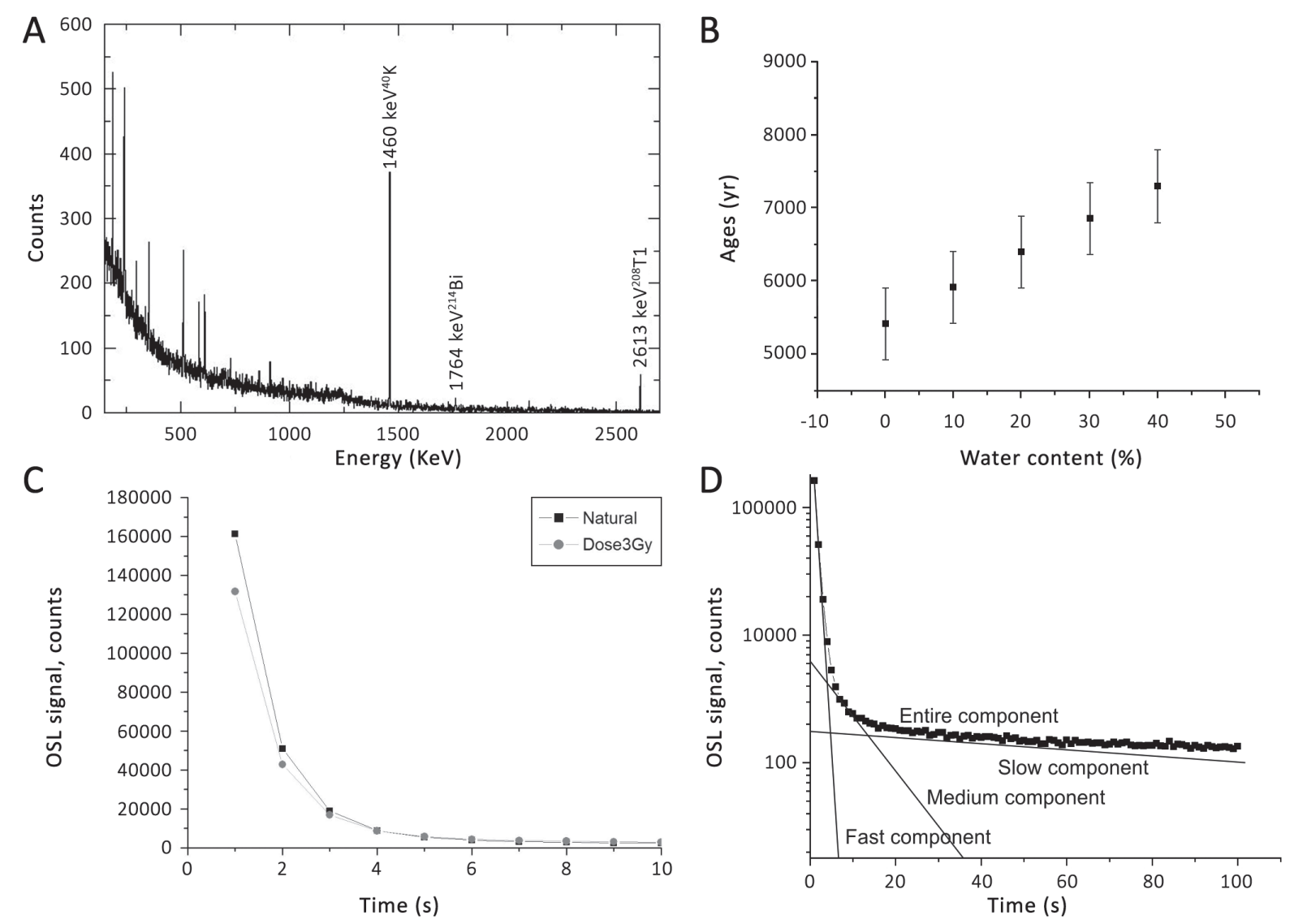

Figure 2 - A: Gamma rays spectrum obtained with a high resolution HPGe detector for the sample IC-3-FML-2 (Ilha Comprida). Identified peaks: ${ }^{40} \mathrm{~K},{ }^{214} \mathrm{Bi}$ (chain of ${ }^{238} \mathrm{U}$ ) and ${ }^{208} \mathrm{Tl}$ (chain of ${ }^{232} \mathrm{Th}$ ). B: Apparent age (with error) of sample IC-3-FML-2 when different values for the water content are used to calculate the radiation dose rate. $\mathbf{C}$ : Natural OSL signal and OSL signal after laboratory irradiation with $\sim 3$ Gy of beta radiation for sample IC-3-FML-2 (Ilha Comprida). D: The natural signal can be decomposed into three components (D).

For most samples, the contribution of cosmic radiation to the dose rate is around 30\% (Table II). However, when $\mathrm{U}, \mathrm{Th}$, and $\mathrm{K}$ concentrations are low (e.g. quartz sands with low heavy mineral contents), the relative contribution of the cosmic radiation can surpasses 50\% (sample LM-19-B, Table II). Samples from the same area have different relative contributions of cosmic radiation to the dose rate due to their different burial depths. Another approach to improve the estimate of the cosmic dose rate is in situ measurements. In situ measurements of cosmic radiation (Sallun et al. 2007) at two different regions in Brazil (São Paulo and Piauí States) showed discrepancies of $\sim 20 \%$ compared to estimates obtained with the equations of Barbouti and Rastin (1983) and Prescott and Stephan (1982). These differences are probably related to hourly isolated measurements, which did not take into account monthly or interannual natural variations which average out over the timescale of OSL dating. While reliable information about changes in cosmic radiation during the Quaternary is not available, the approaches of Barbouti and Rastin (1983) and Prescott and Stephan (1982) are the best methods to obtain a theoretical average value for cosmic radiation at the sampling site, although they are still approximations and have relatively high uncertainty.

Another important factors that should be considered for dose rate estimation are the geochemistry and the radioactive equilibrium of the 
TABLE II

Sample characteristics, equivalent radiation doses and OSL ages obtained.

\begin{tabular}{|c|c|c|c|c|c|c|c|c|c|c|c|c|}
\hline Sample & $\begin{array}{l}\text { Elevation } \\
\text { (m) }\end{array}$ & $\begin{array}{c}\text { Sampling } \\
\text { depth } \\
\text { (m) }\end{array}$ & Type & $\begin{array}{c}\text { Water } \\
\text { content } \\
(\%)\end{array}$ & $\begin{array}{c}\mathrm{Th} \\
(\mathrm{ppm})\end{array}$ & $\begin{array}{c}\mathrm{U} \\
(\mathrm{ppm})\end{array}$ & $\begin{array}{l}\mathrm{K} \\
(\%)\end{array}$ & $\begin{array}{c}\text { Total } \\
\text { Dose rate } \\
(\mathrm{mGy} / \mathrm{y})\end{array}$ & $\begin{array}{l}\text { Cosmic dose } \\
\text { rate }(\mathrm{mGy} / \mathrm{y})\end{array}$ & $\begin{array}{c}\text { Aliquots } \\
\text { (accepted/ } \\
\text { total) }\end{array}$ & $\begin{array}{l}\text { Dose } \\
\text { (Gy) }\end{array}$ & $\begin{array}{l}\text { Age } \\
(\mathrm{ka})\end{array}$ \\
\hline IC-3-FML-2 & 1.5 & 2.8 & $\begin{array}{c}\text { Shallow } \\
\text { marine }\end{array}$ & 10 & $\begin{array}{c}0.501 \pm \\
0.016\end{array}$ & $\begin{array}{c}0.042 \pm \\
0.001\end{array}$ & $\begin{array}{c}0.466 \pm \\
0.024\end{array}$ & $\begin{array}{c}0.611 \pm \\
0.44\end{array}$ & $\begin{array}{c}0.1416 \pm \\
0.0071(23 \%)\end{array}$ & $24 / 24$ & $\begin{array}{c}3.6 \pm \\
1.5\end{array}$ & $\begin{array}{c}6.0 \pm \\
0.5\end{array}$ \\
\hline IC-55-CI-2 & 3 & 0.7 & $\begin{array}{c}\text { Shallow } \\
\text { marine }\end{array}$ & 17.8 & $\begin{array}{c}1.471 \pm \\
0.074\end{array}$ & $\begin{array}{c}0.521 \pm \\
0.004\end{array}$ & $\begin{array}{c}0.343 \pm \\
0.034\end{array}$ & $\begin{array}{c}0.635 \pm \\
0.042\end{array}$ & $\begin{array}{c}0.1641 \pm \\
0.0082(25 \%)\end{array}$ & $21 / 24$ & $\begin{array}{c}0.13 \pm \\
0.01\end{array}$ & $\begin{array}{c}0.21 \pm \\
0.02\end{array}$ \\
\hline IC-39-CI & 5 & 0.4 & $\begin{array}{c}\text { Shallow } \\
\text { marine }\end{array}$ & 13 & $\begin{array}{c}1.483 \pm \\
0.096\end{array}$ & $\begin{array}{c}0.181 \pm \\
0.014\end{array}$ & $\begin{array}{c}0.485 \pm \\
0.039\end{array}$ & $\begin{array}{c}0.716 \pm \\
0.052\end{array}$ & $\begin{array}{c}0.1674 \pm \\
0.0084(23 \%)\end{array}$ & $20 / 24$ & $\begin{array}{c}3.4 \pm \\
1.4\end{array}$ & $\begin{array}{c}4.8 \pm \\
0.4\end{array}$ \\
\hline LM-24EB & 20 & 4 & Eolian & 9.0 & $\begin{array}{c}10.032 \pm \\
0.368\end{array}$ & $\begin{array}{c}1.145 \pm \\
0.010\end{array}$ & $\begin{array}{c}0.046 \pm \\
0.004\end{array}$ & $\begin{array}{c}1.080 \pm \\
0.076\end{array}$ & $\begin{array}{c}0.1512 \pm \\
0.0076(16 \%)\end{array}$ & $10 / 24$ & $\begin{array}{c}125 \pm \\
5\end{array}$ & $\begin{array}{c}116 \pm \\
10\end{array}$ \\
\hline LM-1c-1 & 15 & 1.2 & Fluvial & 2.5 & $\begin{array}{c}1.202 \pm \\
0.033\end{array}$ & $\begin{array}{c}0.773 \pm \\
0.001\end{array}$ & $\begin{array}{c}0.014 \pm \\
0.001\end{array}$ & $\begin{array}{c}0.439 \pm \\
0.030\end{array}$ & $\begin{array}{c}0.1626 \pm \\
0.0081(37 \%)\end{array}$ & $24 / 24$ & $\begin{array}{c}17.4 \pm \\
0.7\end{array}$ & $\begin{array}{c}39.7 \pm \\
3.2\end{array}$ \\
\hline LM-19-B & 47 & 3.6 & Eolian & 2.6 & $\begin{array}{c}1.107 \pm \\
0.010\end{array}$ & $\begin{array}{c}0.275 \pm \\
0.001\end{array}$ & $\begin{array}{c}0.002 \pm \\
0.001\end{array}$ & $\begin{array}{c}0.295 \pm \\
0.023\end{array}$ & $\begin{array}{c}0.1534 \pm \\
0.0077(52 \%)\end{array}$ & $18 / 24$ & $\begin{array}{c}4.9 \pm \\
0.2\end{array}$ & $\begin{array}{c}16.6 \pm \\
1.5\end{array}$ \\
\hline LM-40 & 85 & 2 & Eolian & 0.3 & $\begin{array}{c}2.312 \pm \\
0.028\end{array}$ & $\begin{array}{c}0.480 \pm \\
0.002\end{array}$ & $\begin{array}{c}0.026 \pm \\
0.002\end{array}$ & $\begin{array}{l}0.465 \pm \\
0.033\end{array}$ & $\begin{array}{c}0.1610 \pm \\
0.0080(35 \%)\end{array}$ & $21 / 24$ & $\begin{array}{c}8.3 \pm \\
0.4\end{array}$ & $\begin{array}{c}17.8 \pm \\
1.5\end{array}$ \\
\hline LM-25E & 20 & 12 & Fluvial & 2.1 & $\begin{array}{c}1.371 \pm \\
0.036\end{array}$ & $\begin{array}{c}0.472 \pm \\
0.002\end{array}$ & $\begin{array}{c}0.070 \pm \\
0.006\end{array}$ & $\begin{array}{c}0.397 \pm \\
0.030\end{array}$ & $\begin{array}{c}0.1233 \pm \\
0.0062(31 \%)\end{array}$ & $15 / 33$ & $\begin{array}{c}137 \pm \\
6\end{array}$ & $\begin{array}{c}346 \pm \\
30\end{array}$ \\
\hline
\end{tabular}

sample. Radionuclides produced by the radioactive decay of Th and $\mathrm{U}$ can present different geochemical properties. For example, ${ }^{234} \mathrm{Th}$ is particle adhesive, while its daughter ${ }^{234} \mathrm{U}$ is easily soluble under oxidizing conditions (Anjos et al. 2006). To evaluate possible leaching and, consequently, changes in the dose rate since burial, an analysis of the isotopes in the radioactive decay chain can be performed with high-resolution gamma spectrometry. However, it is difficult to determine when the leaching occurred and to correct the annual dose accordingly. When an imbalance is detected, a higher error can be attributed to the dose rate.

\section{MeAsurement of EQuivalent-Dose}

The main objective of the luminescence measurements is to determine the total ionizing radiation dose received by the sediment since burial, allowing to determine its age of deposition. However, OSL dating of single-grains of quartz has been also used to verify post-depositional disturbance on archeological sites by Araujo et al. 2008 and Feathers et al. 2010. The luminescence signal due to the absorbed radiation dose can be measured by stimulating the sample (usually quartz or feldspar) with light of one wavelength and monitoring the luminescence (OSL) at another wavelength. However, the amount of light emitted for a fixed radiation dose varies from one sample to another, and among aliquots of the same sample. This variation in sensitivity among samples is the result of different source rocks and sedimentary histories (Preusser et al. 2006, 2009, Pietsch et al. 2008, Alexanderson and Murray 2009, Zheng et al. 2009, Fitzsimmons et al. 2010, Sawakuchi et al. 2011). Thus, there is not a general relationship between the luminescence intensity and the radiation dose, i.e. a single dose-response curve applicable to all samples is unreliable. This dose-response curve has to be build for each sediment aliquot, with the estimation of the natural dose of each sample being represented by the average of many aliquots.

The OSL signal of quartz has an exponentially decaying behavior (Fig. 2c) in which the majority of the luminescence is emitted during the first seconds 
of stimulation. Three components (Fig. 2d) named fast, medium and slow (Bailey et al. 1997) according to their increasing decay times are generally used to describe the OSL of quartz. However, up to seven OSL components have been identified (Jain et al. 2003). Usually, the fast component is dominant and is used in OSL dating protocols. In cases with medium and slow components dominance, the application of conventional dating protocols is impaired (Steffen et al. 2009). All the samples analyzed in this study showed a high intensity fast component signal, which dominates the light emission.

The most common approach to luminescence dating is to measure the signal of an aliquot which is composed of tens to hundreds of grains. The signal of the aliquot is the sum of the signals of all grains. The OSL sensitivities of these grains can vary by two to three orders of magnitude (Pietsch et al. 2008, Sawakuchi et al. 2011). Commonly, few grains dominate the OSL signal of sediments (Rhodes 2007). The OSL sensitivity distribution of quartz grains from eolian and beach deposits from Ilha Comprida showed that only $10 \%$ of the grains contribute $50-60 \%$ of the signal of an aliquot (Sawakuchi et al. 2011). Single-grain analyzes of central Brazilian sediments showed a $68.8 \%$ of quartz dim grains (Feathers et al. 2010).

In the SAR protocol (Table I), measurements to build the dose-response curve and the natural signal are carried out with a single aliquot. This prevents the use of aliquots with different OSL sensitivities, giving dose response curves more reliable than those obtained through multiple aliquot protocols. Moreover, a test dose is applied after each irradiationheating-illumination cycle as a way to correct the OSL sensitivity variations of the aliquot during the SAR procedure. In order to evaluate the quality of the aliquot as a dosimeter, the dose recovery, recycling ratio, recuperation and feldspar presence tests are performed (Murray and Wintle 2000). The estimated natural dose value for a sample is the average of several aliquots (at least 15 aliquots that passed the tests). In the next section, we investigate the performance of selected samples from Brazil in those tests and others characteristics important for luminescence dating such as dose distribution and OSL signal saturation.

\section{OSL SENSITIVITY AND RECYCLING RATIO}

The OSL sensitivities of quartz from the Ilha Comprida Barrier and Lençóis Maranhenses coastal zone are relatively high, with OSL curves whose light emissions decay during the first seconds, indicating domination by fast components. Linear modulated OSL measurements on quartz single grains from Ilha Comprida sediments confirm the predominance of the fast component (Sawakuchi et al. 2011). Quartz grains from both regions are suitable for OSL dating, but there are significant differences in their luminescence characteristics. The quartz aliquots from Ilha Comprida are approximately 20 times more sensitive than the quartz aliquots from Lençóis Maranhenses. As a result, the Ilha Comprida quartz is more suitable for dating of young samples.

Measurements performed on 24 quartz aliquots (around 400 grains each) from a Lençóis Maranhenses sample (LM-40) showed a wide distribution of sensitivity values (Fig. 3a). A similar distribution was observed by Sawakuchi et al. (2011) on quartz single grains of fluvial, eolian and shallow marine sediments from southeastern Brazil (São Paulo State). This high variation in sensitivity among aliquots prevents the use of multiple aliquot dating protocols. The SAR protocol is not affected by this variation in OSL sensitivity, since all measurements for equivalent dose estimation are carried out in single aliquots.

We observed different trends in OSL sensitivity variation during the SAR protocol measurements for equivalent dose estimation in 24 quartz aliquots from the Ilha Comprida sample IC-39-CI (Fig. 3b). While the sensitivity of some aliquots decreased by $30 \%$, others aliquots showed a sensitivity increase of 20 to $30 \%$. On the other hand, the Lençóis 
Maranhenses samples present a large increase in OSL sensitivity when a high laboratory radiation dose is applied (Fig. 3c).
The correction of OSL sensitivity changes during the SAR protocol is one of the most important advances in luminescence dating.
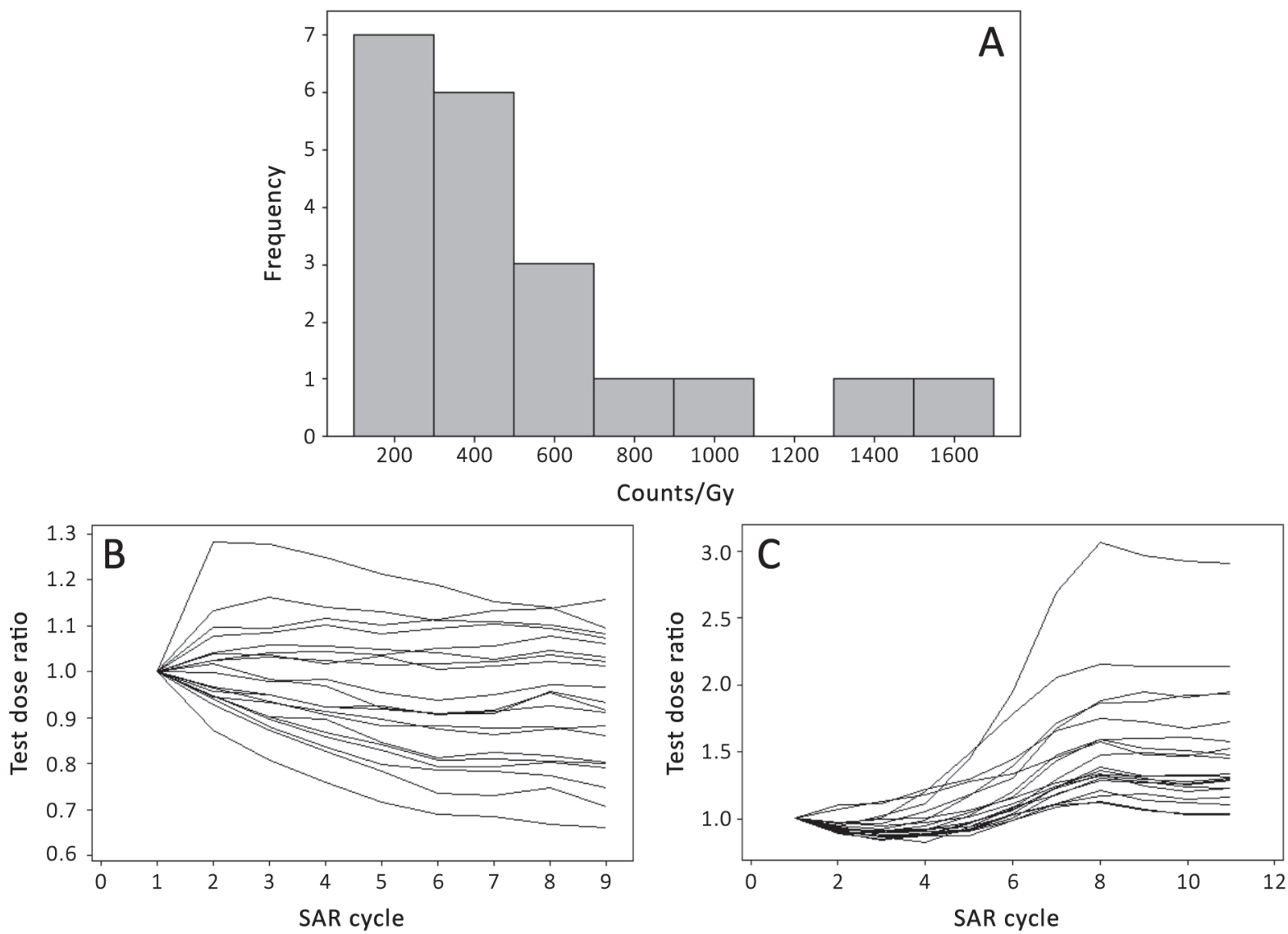

Figure 3 - A: Distribution of OSL sensitivities for 24 quartz aliquots from the sediment sample LM-40 (Lençóis Maranhenses). B and C: OSL sensitivity changes monitored with test dose signals during the application of the SAR protocol. These data correspond to 24 quartz aliquots from samples IC-39-CI (B) and LM-24EB (C), respectively from the Ilha Comprida Barrier and Lençóis Maranhanses coast. For sample LM-24EB, major changes occur during the application of the higher doses in cycles 5 to 8 , comprising doses of 100, 170, 300 and 220 Gy, respectively. The OSL sensitivity changes are smaller during the application of low doses up to $50 \mathrm{~Gy}$.

The effectiveness of this correction is tested using the recycling ratio. The test is usually performed by repeating the smallest radiation dose used to build the dose-response curve. If the sensitivity correction works properly, the corrected signals for both radiation doses in the beginning and in the end of the sequence of measurements should be similar. The ratio between the OSL signals associated with the radiation doses used in the recycling ratio test should varies from 0.9 to 1.1 for reliable sensitivity correction (Murray and Wintle 2000). Values over or under these limits suggest that the sample or the protocol are inappropriate for radiation dose estimation, leading to the rejection of the aliquot.

The Ilha Comprida samples showed reliable sensitivity corrections indicated by recycling ratios between 0.9 and 1.1 (Fig. 4a), as it has been observed in other studies (Sawakuchi et al. 2008, Guedes et al. 2011). Problems with recycling ratios for samples from the northeastern Brazil (Ceará State) were reported by Tsoar et al. (2009). This behavior was also detected in samples from the Lençóis 
Maranhenses coastal zones (Fig. 4b), which only $50 \%$ of the aliquots showed recycling ratios between 0.9 and 1.1. In this case, a higher number of aliquots had to be measured to obtain a reliable radiation dose

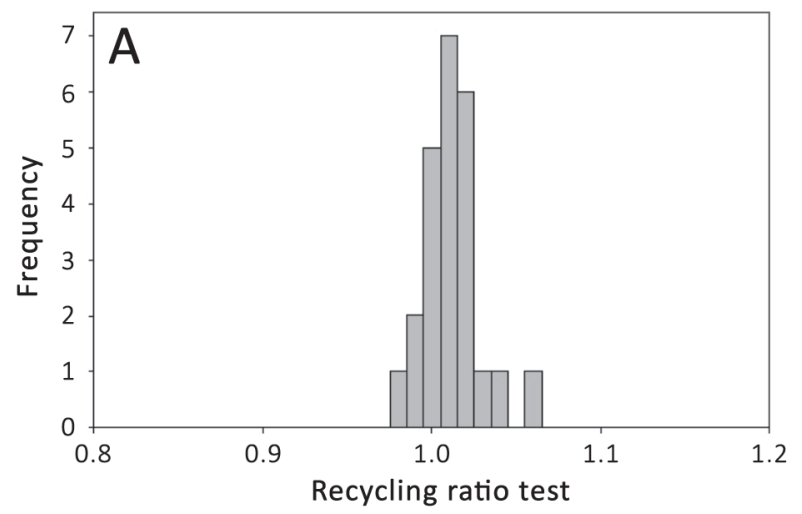

estimate. The difficulty in correct the OSL sensitivity changes of the Lençóis Maranhenses sediments is possibly related to the origin and/or depositional history of their quartz grains.

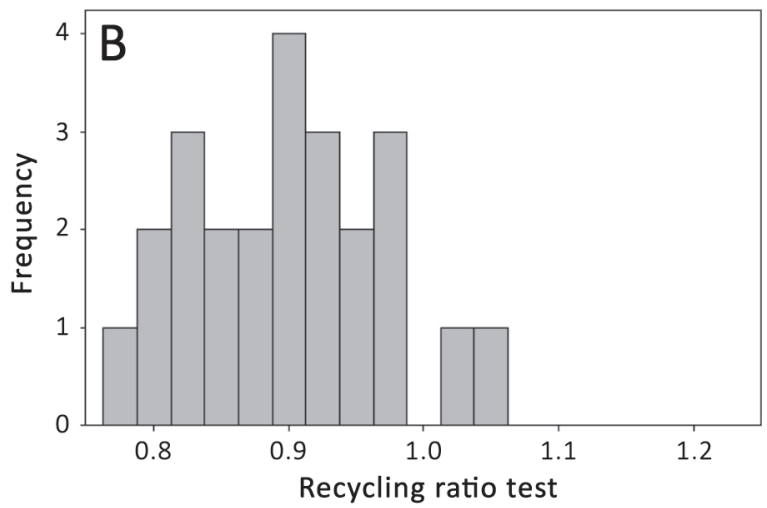

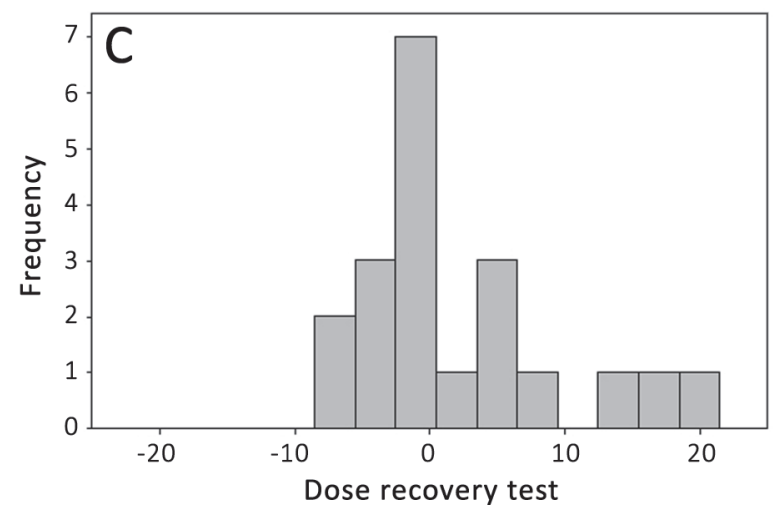

Figure 4 - A and B: Histograms of recycling ratio tests performed for samples IC-3-FML-2 (A) and LM-24EB (B). For sample IC-3-FML-2, the recycling ratio values show a low dispersion and are centered near 1. For LM-24EB, 50\% of the aliquots fail the test. C: Dose recovery tests performed with Lençóis Maranhenses samples (LM-1c-1, LM-19B, LM-24EB and LM-40). The mode near zero shows that most of the samples can be used as a natural radiation dosimeter. However, some samples exceed the $10 \%$ limit of the recycling ratio test.

\section{DOSE RECOVERY TEST}

The dose recovery test evaluates the capacity of the aliquot to behave as a natural dosimeter. It is also used to verify if the experimental parameters used in the SAR protocol are adequate, because it provides estimates for a radiation dose close to the natural radiation dose. This test is performed bleaching the aliquots by either sunlight exposure or an extended light stimulation in the laboratory. A known radiation dose approximating the natural dose is applied and the SAR procedure is performed to estimate the laboratory applied dose.
The difference between the known laboratory dose and the estimated dose using the SAR protocol shall not exceed $10 \%$ (Fig. 4c). This test also evaluates the correction of the OSL sensitivity changes during the first pre-heating (Wintle and Murray 2006). The application of this test on four samples from Lençóis Maranhenses coast (five aliquots for each sample) showed reliable results (Fig. 4c) with small differences between applied and recovered doses (mode near zero). However, two aliquots of sample LM-24EB exceeded the $10 \%$ limit. Thus, an especial attention should be taken to this sample 
while performing the SAR protocol. Feathers et al. (2010) also obtained reliable dose recovery results for samples of central Brazil but underestimation of the given dose was observed by Araujo et al. (2008) at a nearby site. The reasons by this underestimation were not clear (Araujo et al. 2008).

\section{RECUPERATION TEST}

The recuperation test is the measurement of the zero dose point of the dose-response curve. It is assumed that the signal from a zero dose should be within the background. However, a signal above the background can indicate transfer of charge from deeper traps due to previous heating, irradiation and optical stimulation. The test is performed by comparing the corrected signal from a zero dose and the corrected natural signal. The zero dose corrected OSL signal should be less than $5 \%$ of the corrected natural signal, otherwise small equivalent doses for young samples with a very low natural signal would be unreliable. Using the SAR procedure as described in Table I, all 24 analyzed aliquots of sample ICL-6 failed the recuperation test, with a mean recuperation of $9.5 \%$. To overcome this issue, we added an additional stimulation for $40 \mathrm{~s}$ at $260^{\circ} \mathrm{C}$ at the end of the SAR sequence (following step 6 in Table I) as recommended by Wintle and Murray (2006). As a result, the recuperation decreased to $3.4 \%$ (mean of 24 aliquots) and only three aliquots failed the recuperation test. Comparing the estimated doses for both set of aliquots, a difference of $6 \%$ was observed in the final results. Dose estimates were 140 mGy without and $132 \mathrm{mGy}$ with the additional step.

\section{INCOMPLETE BLEACHING}

A premise of luminescence dating is that the sediment has undergone complete bleaching prior to burial. If the bleaching is incomplete, the age will be overestimated, and the dose distribution is different from a normal distribution. The OSL fast component used for OSL dating is bleached within minutes to seconds of sunlight exposure (Aitken
1998) while the thermoluminescence (TL) traps take several hours to be bleached (Preusser et al. 2009). This makes OSL dating of sediments advantageous in relation to TL dating. While eolian sediments rarely present problems related to sunlight exposure, subaqueous sediments such as shallow marine and especially fluvial commonly display incomplete bleaching, particularly regarding the TL signal. The frequency distribution of estimated doses of well bleached aliquots measured with the SAR protocol tends to be normal (Fig. 5a) as found for shallow marine sample IC-3-FML-2 from Ilha Comprida. This behavior of the dose distribution is indicative of complete bleaching prior the burial. A distribution different from the normal with large dispersion (Fig. 5b), as showed by a fluvial sediment sample from the Lençóis Maranhenses region (LM-1c-1), is indicative of incomplete bleaching. Incomplete bleaching was suggested by Sallun and Suguio (2007) as a reason for the wide dispersion of the estimated dose values in some fluvial samples from the Paraná Alloformation and colluvial samples from the Paranavaí Formation in southeastern Brazil. In those cases, aliquots with few grains or even single grains should be measured to avoid insufficiently bleached grains. Linear modulated OSL on singlegrains measurements were performed to analyze partial bleaching and post-depositional disturbance on archeological sites at central Brazil by Feathers et al. (2010) and Bueno et al. (2012). The authors concluded that post-depositional disturbance is the main factor responsible for higher scatter of estimated dose distributions.

\section{OSL SignAL AND AGE RANGE}

The lower age limit in luminescence dating is determined by the OSL sensitivity and the detection limit of the OSL signal in relation to the background. Ages of few decades have been determined (Ballarini et al. 2003, Madsen et al. 2005, Sawakuchi et al. 2008). Sawakuchi et al. (2008) obtained ages of less than one century and estimated doses of less 

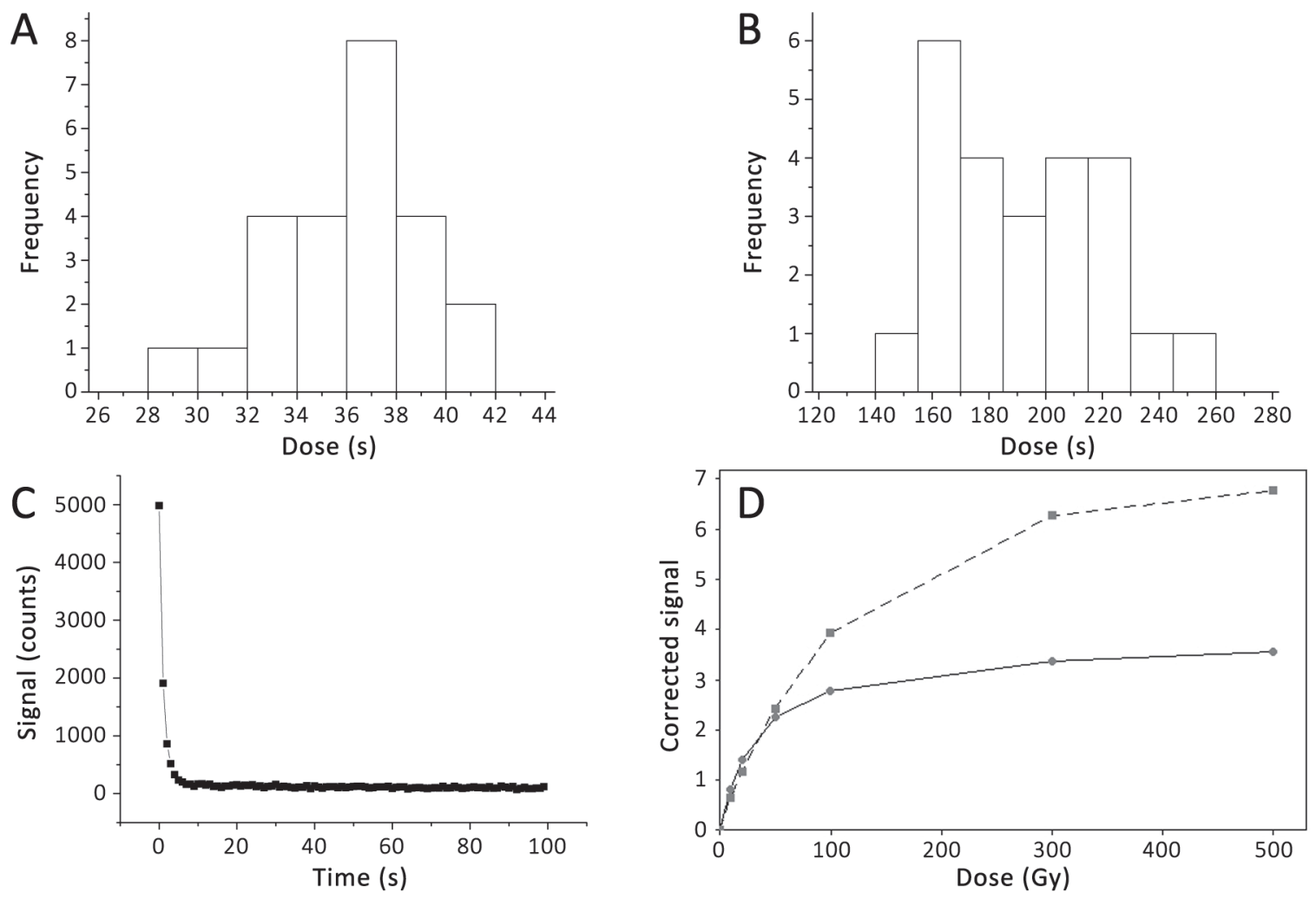

Figure 5 - A and B: Distribution of estimated doses for a shallow marine (A) and a fluvial sediments samples (B). The shallow marine sample shows a normal distribution, as expected for sediments with sufficient bleaching prior to burial. However, the fluvial sample shows a bimodal distribution, probably as result of incomplete bleaching before burial. C: Natural OSL signal of the sample IC-55-CI-2 with an estimated dose of less than $100 \mathrm{mGy}$ and an age of few decades. D: Dose-response curve for two different aliquots of sample LM-25E from Lençóis Maranhenses. While the equivalent dose for aliquot one saturates around 100 Gy (single exponential curve, solid line), aliquot two saturates at doses above $300 \mathrm{~Gy}$ and the dose response is best described by the sum of two exponential curves (dashed line). These variations in the dose-response curves among aliquots of the same sample indicate the need for great caution when dating samples with high natural doses, near the limit of saturation.

than 100 mGy for the Ilha Comprida samples. Even for low natural doses, the high OSL sensitivity of the Ilha Comprida quartz results in a signal well distingueshed from background (Fig. 5c).

For increasing radiation doses, the luminescence signal shows an exponentially saturating trend. This saturation value varies among samples, but is commonly in the range from 100 to 200 Gy for quartz (Wintle 2008). Therefore, the upper age limit depends on the saturation dose and the dose rate of the sample. Lower dose rates result in higher age limits. Recent studies (Murray et al. 2007, 2008, Preusser et al. 2009, Lowick et al. 2010a, b, Pawley et al. 2010) observed that the saturation curve of quartz is best described by the sum of two exponential curves, one rapidly saturating and another that saturates more slowly, or even the sum of an exponential and a linear curve (Fig 5d). The measurement of dose values up to 600 Gy (Pawley et al. 2010) and the construction of dose response curves up to 1,000 Gy (Lowick et al. 2010b) allowed to extend the upper age limit, obtaining ages of up to 250,000 years for quartz aliquots (Murray et al. 2008). However, caution must be taken in estimating doses near the saturation limit of the sample. Murray et al. (2008) and Pawley et al. (2010) observed an underestimation of the dose of around $10 \%$ in samples with high natural doses $(>150$ Gy), probably resulting from an unstable medium 
component. The fluvial sample LM-25E, which was interpreted in the field as collected in the Barreiras Formation of Miocene age, is a good example for the complexity of interpreting results for samples near or above the OSL saturation limit. From a total of 33 analyzed aliquots, four were saturated and 14 failed in the SAR tests. While some aliquots showed a simple exponential saturation dose-response curve and doses in the saturated region, others are better described as a sum of two exponential curves and dose results are below the saturation limit. The estimated dose for this sample was $137 \pm 6$ Gy, near the saturation limit proposed by Wintle (2008), with a dose distribution showing a wide dispersion, probably as a result of incomplete bleaching. The calculated age of $345 \pm$ $30 \mathrm{ka}$ for this sample is unreliable regarding the dose distribution and the near saturation estimated dose. This OSL age does not match with the expected Miocene age for the Barreiras Formation estimated through microfossils content (Arai 1997).

\section{CONCLUSIONS}

Luminescence dating is widely applied in Quaternary studies. Advances in protocols for equivalent dose estimation during the last decade, such as the development of the SAR protocol, improved OSL dating reliability. Brazil has a wide and stable cratonic area and most of the Quaternary sediments are composed predominantly of quartz. The analyzed Brazilian sediments showed good behavior regarding their luminescence characteristics, such as high sensitivity and adequate dose-response curves. However, variations in sample characteristics and sample sites can influence the final result. Thus, a critical analysis of the results for each sample must take into account the overall characteristics of the quartz sample and sample site.

\section{ACKNOWLEDGMENTS}

This work was funded by Fundação de Amparo à Pesquisa do Estado de São Paulo (FAPESP 2007/51511-4 and 2009/10521-2). The authors are grateful to the two anonymous reviewers who provided constructive comments on the manuscript.

\section{RESUMO}

Esse estudo analisa as características da luminescência opticamente estimulada (LOE) de grãos de quartzo de areias fluviais, eólicas e marinhas rasa de areias do nordeste e sudeste brasileiro, com vistas para avaliar a aplicabilidade do protocolo SAR (single-aliquot regenerative dose). Todos os sedimentos analisados apresentam alta sensibilidade LOE e bom comportamento relativo às características de luminescência relevantes à estimativa de dose de radiação. No entanto, algumas amostras de sedimentos da costa maranhense apresentaram dificuldades na correção da sensibilidade da luminescência, o que dificulta a aplicação do protocolo SAR e seu uso como dosímetro natural. Enquanto as amostras de sedimentos marinhos rasos e eólicos analisados apresentaram distribuições de dose com dispersão reduzida, a amostra de sedimentos fluviais possui distribuição de dose com elevada dispersão, indicativa de foto-esvaziamento parcial e estimativa de dose pouco confiável. LOE entre amostras, uma análise crítica das doses estimadas para cada amostra deve levar em consideração as características do local de coleta da amostra e de luminescência do quartzo.

Palavras-chave: Datação por luminescência opticamente estimulada (LOE), protocolo de datação por alíquota única (SAR), sensibilidade LOE, sedimentos arenosos brasileiros.

\section{REFERENCES}

ADAMIEC G AND AITKEN M. 1998. Dose-rate conversion factors: update. Anc. TL 16(2): 37-50.

AITKEN MJ. 1998. An Introduction to Optical Dating. London: Oxford University Press, 267 p.

AleXanderson H AND Murray AS. 2009. Problems and potential of OSL dating Wiechselian and Holocene sediments in Sweden. Quat Sci Rev xx: 1-14.

Anjos RM, Veiga R, Macario K, CARVAlho C, SANChes N, BASTOS J AND, GOMES PRS. 2006. Radiometric analysis of Quaternary deposits from the southeastern Brazilian coast. Mar Geol 229: 29-43.

ARAi M. 1997. Dinoflagelados (Dinophyceae) miocênicos do Grupo Barreiras do Nordeste do estado do Pará (Brasil). Rev Uni Guarulhos 2: 98-106. 
Araujo AGM, FeATHERs JK, ARroyo-Kalin M AND TizUKA MM. 2008. Lapa das boleiras rockshelter: stratigraphy and formation processes at a paleoamerican site in Central Brazil. J Archaeolog Sci 25: 3186-3202.

Bailey RM, SMith BW AND Rhodes EJ. 1997. Partial bleaching and the decay form characteristics of quartz OSL. Radiat Meas 27: 123-136.

Ballarini M, Wallinga J, Murray as, Van Heteren S, OOST AP, Bos AJJ AND VAN EIJK CWE. 2003. Optical dating of young coastal dunes on a decadal time scale. Quat Sci Rev 22: 1011-1017.

BanerJeE D, Bøtter-Jensen L AND Murray AS. 1999. Retrospective Dosimetry: preliminary use of the single aliquot regeneration (SAR) protocol for the measurement of quartz dose in young house bricks. Radiat Prot Dosime 84: 421-426.

BARBOUTI A AND RASTIN B. 1983. A Study of the absolute intensity of muons at sea level and under various thicknesses of absorber. J Phys G: Nucl Phys 9: 1577-1595.

BARRETO AMF, Suguio K, TATUMi SH, YeE M, GiANNINI PCF AND BEZERRA FHR. 2001. Dunas inativas do Rio Grande do Norte: idades, áreas-fonte e possíveis correspondências com o nível relativo do mar no Quaternário. In: SIMPÓSIO REGIONAL DE GEOLOGIA DO NORDESTE. Boletim de Resumos... Recife, SBG.

BATEMAN MD, BOUlter CH, CARR AS, FREDERICK CD, Peter D AND Wilder M. 2007. Preserving the palaeoenvironmental record in Drylands: Bioturbation and its significance for luminescence-derived chronologies. Sedim Geol 195: 5-19.

Bueno L, Feathers J AND De Blasis P. 2012. The formation process of a paleoindian open-air site in Central Brazil: integrating lithic analysis, radiocarbon and luminescence dating. J Archaeolog Sci 40: 190-203.

CAMPanha GAC AND SADOWSKI GR. 1999. TECTONICS OF THE Southern Portion of the Ribeira Belt (Apiaí Domain). Precambrian Res 98: 31-51.

Feathers J, Kupnis R, Piló L, Arroyo-Kalin M AND CoBlentz D. 2010. How old is Luzia? Luminescence dating and stratigraphic integrity at Lapa Vermelha, Lagoa Santa, Brazil. Geoarchaeology 1: 395-436.

FITZSIMMONS KE, RHODES EJ AND BARROws TT. 2010. OSL dating of southeast Australian quartz: A preliminary assessment of the luminescence characteristics and behaviour. Quat Geochronol 5: 91-95.

GiANNINI PCF, GUEDES CCF, NASCIMENTO DR, TANAKA APB Angulo RJ, Assine ML AND SouzA MC. 2009. Sedimentology and morphologic evolution of the Ilha Comprida Barrier system, southern São Paulo coast. In: DILLENBURG SR and HESP P (Eds), Geology of the Brazilian coastal barriers: Lecture Notes in Earth Sciences. Springer-Verlag.

GiANNINI PCF, SAWAKUCHI AO, MARTINHO CT AND TATUMI SH. 2007. Eolian depositional episodes controlled by Late Quaternary relative sea level changes on the ImbitubaLaguna coast (southern Brazil). Mar Geol 237: 143-168.
Guedes CCF, Giannini PCF, SAWakuchi AO, Dewitt R, NASCIMENTO DR, AgUiar VAP AND Rossi MG. 2011. Determination of controls on Holocene barrier progradation through application of OSL dating: The Ilha Comprida Barrier example, Southeastern Brazil. Mar Geol 285: 11-16.

Hesp PA, Maia LM AND Claudino-Sales V. 2009. The Holocene barriers of Maranhão, Piauí and Ceará States, Northeastern Brazil. In: DILLENBURG SR AND HESP P (Eds), Geology of the Brazilian Coastal Barriers. Lecture Notes in Earth Sciences. Berlin: Springer, p. 325-345.

HuNTLEY DJ. 1985. On the zeroing of the thermoluminescence of sediments. Phys Chem Miner 12: 122-127.

JAIN M, Murray AS AND BotTER-JENSEN L. 2003. Characterisation of blue-light stimulated luminescence components in different quartz samples: implication for dose measurement. Radiat Meas 37: 441-449.

Lowick SE, Preusser F, PINI R AND RaVAzZI C. 2010a. Underestimation of fine grains quartz OSL dating towards the Eamian: Comparison with palynostratigraphy from Azzano Decimo, northeastern Italy. Quat Geochronol 5: 583-590.

LOWICK SE, PREUSSER F AND WINTLE AG. 2010b. Investigating quartz optically stimulated luminescence dose-response curves at high doses. Radiat Meas 45: 975-984.

Madsen AT, Murray AS, ANDERSEN TJ, PeJRup M AND BREUNING-MADSEN H. 2005. Optically stimulated luminescence dating of young estuarine sediments: a comparison with $210 \mathrm{~Pb}$ and $137 \mathrm{Cs}$ dating. Mar Geol 214: 251-268.

McKeever SWS, BøtTer-Jensen L, Agersnap-Larsen N, MEJDAH V AND POOLTON NRJ. 1996. Optically stimulated luminescence sensitivity changes in quartz due to repeated use in single aliquot readout: experiments and computer simulations. Radiat Prot Dosim 65(1-4): 49-54.

Murray A, Buylaert J, Henriksen M, Svendsen J AND MANGERUD J. 2008. Testing the reliability of quartz OSL ages beyond the Eamian. Radiat Meas 43: 776-780.

Murray AS, SVEndSEN JI, MANGERUd J AND AstaKhov VI. 2007. Testing the accuracy of quartz OSL dating using a known-age Eamian site on the river Sula, northern Russia. Quat Geochronol 2: 102-109.

MurRAY A AND WintLE AG. 2000. Luminescence dating of quartz using an improved single-aliquot regenerativedose protocol. Radiat Meas 32: 57-73.

NASCIMENTO DR, GIANNINI PCF, TANAKA APB AND GUEDES CCF. 2008. Evidências diretas de mais de 130 anos de mudanças morfológicas e sedimentológicas no entorno da extremidade NE da barreira de Ilha Comprida, SP. São Paulo, Geologia-USP - Série Científica 8: 25-39.

Pawley SM, Toms P, ARMitage SJ AND Rose S. 2010. Quartz luminescence dating of Anglian Stage (MIS 12) fluvial sediments: Camparision of SAR age estimatives to the terrace chronology of the Middle Thames valley, UK. Quat Geochronol 5: 569-582.

Pietsch TJ, Olley JM AND NANSON GC. 2008. Fluvial transport as a natural luminescence sensitiser of quartz. Quat Geochronol 3: 365-376. 
Poupeau G, Soliani Junior EL, Rivera A, Loss EL AND VASCONCELLOS MBA. 1988. Datação por termoluminescência de alguns depósitos arenosos costeiros, do Último Ciclo Climático, no nordeste do Rio Grande do Sul. Pesquisas 21: 25-47.

Poupeau G, Souza JH, Soliani Junior EL AND Loss EL. 1984. Dating quartzose sands of the Coastal Province of Rio Grande do Sul, Brazil, by thermoluminescence. Pesquisas 16: 250-268.

PRESCOTT JR AND STEPHAN LG. 1982. The contribution of cosmic radiation to the environmental dose for thermoluminescence dating. In: Proceedings of the Second Specialist Seminar on Thermoluminescence Dating 6, Council of Europe, Strasbourg, p. 17-25.

Preusser F, Chithambo ML, Götte T, Martini M, RAMSEyer K, SENDEZERA EJ, Susino GJ AND Wintle AG. 2009. Quartz as a natural luminescence dosimeter. Earth Sci Rev 97: 184-214.

PReusser F, RAMSEYeR K AND SCHLÜCHTER C. 2006. Characterization of low OSL intensity quartz from the New Zealand Alps. Radiat Meas 41: 871-877.

RHODES EJ. 2007. Quartz single grain OSL sensitivity distributions: implications for multiple grain single aliquot dating. Geochronometria 26: 19-29.

SAllun AEM AND Suguio K. 2007. Datação absoluta por luminescência do alogrupo Alto Rio Paraná (SP, PR e MS). Rev Inst Geol 27-28(1): 13-29.

SALLUN AEM AND SUGUIO K. 2010. Quaternary colluvial episodes (Upper Paraná River Hydrographic Basin, Brazil). An Acad Bras Cienc 82: 701-715.

Sallun AEM, Suguio K, Tatumi SH, Yee M, Santos J And BARRETO AMF. 2007. Datação absoluta de depósitos quaternários brasileiros por luminescência. Rev Bras Geoc 37(2): 402-413.

SAWAKUCHI AO, BLAIR MW, DEWITT R, FALEIROS FM, Hyppolito T AND Guedes CCF. 2011. Thermal history versus sedimentary history: OSL sensitivity of quartz grains extracted from rocks and sediments. Quat Geochronol 6: 261-272.

SAWAKUCHI AO, KaLCHGRUBER R, GIANNINI PCF, NASCIMENTO JR DR, GUEDES CCF AND UMISEDO N. 2008. The development of blowouts and foredunes in the Ilha Comprida barrier (Southeastern Brazil): the influence of Late Holocene climate changes on coastal sedimentation. Quat Sci Rev 27: 2076-2090.
Schobbenhaus C AND Bellizia A (COORD). 2001. Mapa Geológico da América do Sul, 1:5.000.000, CGMWCPRM-DNPM-UNESCO, Brasília.

SOARES EAA, TATUMI SH AND RICCOMINI C. 2010. OSL age determination of Pleistocene fluvial deposits in Central Amazonia. An Acad Bras Cienc 82: 691-699.

StefFEN D, Preusser F AND SChlunegger F. 2009. OSL quartz age underestimation due tounstable signal components. Quat Geochronol 4: 353-362.

Suguio K, TATumi SH And Kowata EA. 1999. The Comprida Island inactive dune ridges and their possible significance for the island evolution during the Holocene, State of São Paulo, Brazil. An Acad Bras Cienc 71: 623-630.

Suguio K, Tatumi SH, Kowata EA, Munita CS and Paiva RP. 2003. Upper Pleistocene deposits of the Comprida Island (São Paulo State) dated by thermoluminescence method. An Acad Bras Cienc 75: 91-96.

TAtumi SH, Silva LP, PIRES EL, Rossetti DF, GóES AM AND MunitA C. 2008. Datação de sedimentos Pós-Barreiras no norte do Brasil: implicações paleogeográficas. Rev Bras Geoc 38(3): 514-524.

TEEUW MR AND RHODES EJ. 2004. Aeolian activity in northern Amazonia: optical dating of Late Pleistocene and Holocene palaeodunes. J Quaternary Sci 19: 49-54.

TSOAR H, LEVIN N, PORAT N, MAIA LP, HERRMANN HJ, TATUMI SH AND CLAUdinO-SALES V. 2009. The effect of climate change on the mobility and stability of coastal sand dunes in Ceará State (NE Brazil). Quat Res 71: 217-226.

VASCONCELOS AM, VEIGA JÚNIOR J, COLARES JQS, RIBEIRO JAP, GOMES IP, MEDEIROS MF AND FORGIARINI LL. 2004. Folha SA.23-São Luís. In: Schobbenhaus C, Gonçalves JH, Santos JOS, Abram MB, Leão Neto R, Matos GMM, Vidotti RM, Ramos MAB and Jesus JDA (Eds), Carta Geológica do Brasil ao Milionésimo, Sistema de Informações Geográficas. Programa Geologia do Brasil. CPRM, Brasília. CD-ROM.

WINTLE AG. 2008. Luminescence dating: where it has been and where it is going. Boreas 37: 471-482.

WINTLE AG AND MURRAY AS. 2006. A review of quartz optically stimulated luminescence characteristics and their relevance in single-aliquot regeneration dating protocols. Radiat Meas 41: 369-391.

ZHENG CX, ZHOU LP AND QIN JT. 2009. Difference in luminescence sensitivity of coarse-grained quartz from deserts of northern China. Radiat Meas 44: 534-537. 